\title{
Translation and Validation of the Coping with Death Scale: A Study with Nurses
}

\author{
Tradução e Validação da Escala de Coping com a Morte: Um Estudo com Enfermeiros \\ Traducción y Validación de la Escala de Afrontamiento de la Muerte: Un Estudio con \\ Enfermeros
}

Ana Paula Forte Camarneiro*; Sara Margarida Rodrigues Gomes**

\begin{abstract}
Theoretical framework: Coping with death allows dealing with death on a daily basis and is a key measure to assess the impact of professional training on the topic.

Objectives: To translate and validate the Coping with Death Scale (Bugen, 1980-81) into Portuguese among Portuguese nurses.

Methodology: Exploratory study of translation/back-translation, followed by psychometric analysis in a sample of 107 nurses working in oncology services.

Results: The scale showed high internal consistency $(\alpha=0.89)$. Following the study on validity, four items from the original version were deleted, and the two-factor solution was maintained (coping with one's own death and coping with the death of others). No gender differences were found. Nurses with training in palliative care had higher levels of coping. Conclusion: The Portuguese version is useful to understand how healthcare professionals cope with death and assess the effectiveness of training in coping with death and dying.
\end{abstract}

Keywords: Scales; coping; death; nursing

\section{Resumo}

Enquadramento: O coping com a morte permite lidar com a morte no quotidiano e é uma medida crucial na avaliação dos efeitos da educação profissional sobre o tema.

Objetivos: Traduzir e validar para português a Coping with Death Scale (Bugen, 1980-81) em enfermeiros portugueses.

Metodologia: Estudo tipo metodológico de tradução/retroversão e análise psicométrica numa amostra de 107 enfermeiros que exercem funções em serviços de oncologia.

Resultados: A escala apresenta elevada consistência interna $(\alpha=$ $0,89)$. Após estudo da validade de construto, foram retirados 4 itens da versão original e manteve-se a solução bifatorial (coping com a própria morte e coping com a morte dos outros). Não se verificaram diferenças significativas conforme o género. Os enfermeiros com formação em cuidados paliativos evidenciaram níveis de coping mais elevados.

Conclusão: A versão portuguesa torna-se útil para conhecer o coping com a morte nos profissionais de saúde e avaliar a eficácia da formação face à morte e morrer.

Palavras-chave: Escalas; adaptação; morte; enfermagem

\footnotetext{
* Ph.D., Adjunct Professor, Nursing School of Coimbra, 3046-851, Coimbra, Portugal [pcamarneiro@esenfc.pt]. Contribution to the article: Supervision of the study design; bibliographic search and analysis of articles on the selected scale; statistical analysis; manuscript preparation, particularly regarding the methodology and results; critical review of the manuscript; and final writing for publication. Address for correspondence: Rua do Açude, n. ${ }^{\circ}$ 150, Quinta da Mainça, 3000-029, Coimbra, Portugal.

** MSc.. Palliative Care. RN, General Surgery Inpatient Unit, Portuguese Institute of Oncology of Coimbra Francisco Gentil (IPOCFG, EPE), 3000-075, Coimbra, Portugal [saramrgomes@gmail.com].Contribution to the article: study design; recruitment of sample subjects; data collection; statistical analysis; bibliographic search; production of text on the literature review and the discussion of results.
}

\section{Resumen}

Marco contextual: El afrontamiento (coping) de la muerte permite lidiar con la muerte en el día a día y es una medida crucial en la evaluación de los efectos de la educación profesional sobre el tema.

Objetivos: Traducir y validar al portugués la Coping with Death Scale (Bugen, 1980-81) en enfermeros portugueses. Metodología: Estudio metodológico de traducción/ retroversión y análisis psicométrico en una muestra de 107 enfermeros que desempeñan su función en servicios de oncología.

Resultados: La escala presenta una elevada consistencia interna $(\alpha=0,89)$. Tras estudiar la validez de constructo, se retiraron cuatro ítems de la versión original y se mantuvo la solución bifactorial (afrontamiento de la muerte en sí mismo y de la muerte en los otros). No hay diferencias significativas en cuanto al género. Los enfermeros con formación en cuidados paliativos observaron niveles de afrontamiento más elevados.

Conclusión: La versión portuguesa es útil para conocer el afrontamiento de la muerte en los profesionales sanitarios y para evaluar la eficacia de la formación ante la muerte y el morir.

Palabras clave: Escalas; adaptación; muerte; enfermería

Received for publication: 27.11.14 Accepted for publication: 23.09 .15 


\section{Introduction}

The professional teams who care for patients in critical condition (oncological or other) often have to deal with the death of many of these patients. Nurses are the professionals who provide more care to these terminal patients in close physical, emotional, social and spiritual proximity.

In oncology care, the helping relationships and the ethical values are emphasised, as well as the numerous mechanisms of resilience mobilised by nurses to control their emotions and anxiety (Popim \& Boemer, 2005). Although effective, these mechanisms are fallible, mainly in situations involving incurable diseases and subsequent death. In general, health professionals report a feeling of anguish regarding the death of their patients and stress while working with their families, which leads to an enormous emotional tension.

Thus, the knowledge, skills and responsibilities of these professionals should be focused on the patient and the family (Stumm, Leite, \& Maschio, 2008). Their personal skills should also be developed, such as the coping strategies, which allow them to deal with death on a daily basis, minimising their suffering and increasing their effectiveness and that of all of those involved.

Coping is the term used to classify the fight or flight responses of the sympathetic nervous system to situations perceived as threatening physical or emotional safety, stress in general (Pais-Ribeiro, 2007). It is a process through which individuals orient their thoughts and behaviours toward resolving the sources of stress and managing emotional reactions (Lazarus, 1993). In summary, it is the ability to solve a problem that arises or resist a situation that proves difficult (Vaz-Serra, 2000).

There are only a few studies in the literature on the development of coping strategies with death and the methods of evaluation of these strategies. However, many authors have reported that the development of education programs on coping strategies is effective to prevent death-related anxiety and identify barriers that may make end-of-life care more difficult (Beckstrand, 2009; Braun, Gordon, \& Uziely, 2010; Dunn, Otten, \& Stephens, 2005). It is known that individuals with high levels of self-efficacy who trust in their abilities to respond to stimuli from the environment tend to use active coping strategies in coping situations at work
(Pocinho \& Capelo, 2009).

A profound inner mobilisation, with consequent availability for the recovery of the feelings mobilised, is required to address the topic, particularly in undergraduate nursing programs. This is a very complex inner task to which some teachers and students tend to resist. For example, in a study with 34 nursing teachers, Santos and Bueno (2011) concluded that teachers remained distant from the students in relation to the feelings resulting from experience with terminally ill patients, because they experience feelings of fear, impotence and insecurity towards death. Thus, they end up developing a technicalscientific and pedagogical approach in which they allege lack of time to promote discussion on the topic, evoking its multidimensional complexity.

This difficulty can be overcome with the introduction (or reinforcement if they already exist) of compulsory and optional curricula in the initial training in nursing that include the knowledge and the development of skills in this area. These curricula would provide a type of awareness for further training in a professional context.

Rickerson et al. (2005) and Fessick (2007) concluded that participating in education sessions on bereavement, identifying coping strategies, creating forums to share feelings, talking to colleagues and friends, joining support groups and accepting individual counselling is beneficial for the nursing team. According to Lobb et al. (2010), the possibility to make use of complementary therapies of well-being, such as massage, reflexology and aromatherapy is also a strategy to facilitate nurses' coping in the workplace. With the purpose of identifying the strategies used by nurses to cope with death, particularly in oncology services, it is important to have an instrument to assess these strategies. This study aims to translate and validate the Coping with Death Scale (Bugen, 1980-81) into Portuguese in a sample of nurses working in oncology services.

\section{Background}

The experience of death by healthcare professionals usually denotes a feeling of professional failure because the progress of medicine has created the illusion of health and life forever. This situation impedes the development of skills in this area and 
the healthcare professionals need to help patients and families to be more competent and effective, thus becoming more effective.

Bugen (1980-81) believes that coping is the most sensitive indicator of death coping skills and wants his students to obtain these skills through seminars and education about death. The results can be observed with the completion of the scale created by the author, the Coping with Death Scale (Bugen, 1980-81), which was later validated by Robbins (1990-91).

Bugen (1980-81) offered training directed to the development of the skills of the volunteers in the palliative care units and the scale that he created included specific competences that volunteers should have acquired after training. Robbins (199091) operationalised the concept of coping with death and used the scale to measure coping in university students and volunteers of palliative care units.

The scale comprises 30 items related to the various aspects of coping with death. It is a self-report 7-point Likert-type scale ranging from 1 to 7 , where 1 is $d o$ not agree at all and 7 agree completely). The final score is achieved through reversing score items 13 and 24, and then total all items.

According to the author of the scale (Bugen, 198081), the several items are organised into two factors: coping with one's own death and coping with the death of others. The first factor includes items such as $2,4,5,10,11,12$ and 14 , which denote a greater understanding, knowledge and expressiveness of emotions, as for example: I understand my deathrelated fears (item 10), I am familiar with funeral prearrangement (item 11), and I can express my fears about dying (item 14). The second factor includes items such as 21, 23, 26, 27, 28 and 29, which are related to increased skills to communicate with, and/ or, help the bereaved and the terminally ill patients, as for example: I can communicate with the dying (item 29), I can belp people with their thoughts and feelings about death and dying (item 26), and I know how to speak to children about death (item 23).

The maximum score of the total sum of the scale items is 210 and the minimum is 30 . The results of the study of Robbins (1990-91) demonstrated that Bugen's scale (1980-81) showed good levels of internal consistency (Cronbach's alpha of 0.89).

The scale showed discriminant validity with the StateTrait Anxiety Inventory and with the Marlowe-Crowne Social Desirability Scale (Robbins, 1990-91).

\section{Methodology}

A methodological study was conducted (Mishel, 1998) that consisted in the translation and validation into Portuguese of the Coping with Death Scale (Bugen, 1980-81). Since we were not familiar with any studies published in Portuguese on this topic, we purchased the articles where the original scale is published without reference to limitations of use. We did not request permission to use the scale as the author is deceased.

The sample was composed of 107 nurses who worked in the various hospitalisation services of an oncologic hospital.

For the translation/back-translation, we used the usual procedures for a linguistic adaptation and identification of equivalent measuring instruments, written in a language other than the original (Hunt, 1993). Thus, in the phase of questionnaire translation, we obtained a Portuguese version that was linguistically correct and equivalent to the American original version. The scale was translated by two independent Portuguese translators fluent in English, thus obtaining two Portuguese versions. This phase was followed by a phase of reconciliation between both translations. The contents were analysed and compared, ensuring that, according to Ferreira and Rosete (1996), the translations lead to results with equivalent interpretations. The discrepancies identified were minimal. These were only related to words that could be translated in many ways into Portuguese.

The first version in Portuguese was back-translated by a professional translator.

Later, a comparative analysis with the original version was conducted, and a group of experts was asked to make a critical reading of the item contents and understanding in terms of semantic and idiomatic aspects, conceptual equivalence and consistency of each item to achieve the proposed objectives and cultural equivalence, given that the situations in the instrument should correspond to those experienced in our culture (Lynn, 1986).

A debate was then held on the questionnaire. No difficulties in understanding or ambiguity in interpretation were identified.

Finally, a pre-test was conducted with a group of ten nurses who answered the questionnaire and made a qualitative evaluation. Items 1 and 4 did not find 
a consensus as to content and relevance, and the experts decided that they would be applied in a larger sample and subjected to construct analysis.

The instrument was applied and its reliability and construct validity were analysed, with a view to finding a consistent factor solution and identify its psychometric properties.

Factor analysis was used to analyse its construct validity. For reasons related to sample size that hinder confirmatory factor analysis, a forced two-factor solution using principal component analysis was used, followed by orthogonal varimax rotation, making the solutions emerging from the analysis interpretable (Loureiro, 2010). The Kaiser-Meyer-Olkin measure (KMO) and the Bartlett's test of sphericity were previously calculated.

The decision on the number of factors to retain in the analysis was based on the proposal of the author of the scale (Bugen, 1980-81), in which eigenvalues should be greater than 1.00 . The choice of the factor solutions complied with the criterion of item-factor convergent validity, with each item showing a factor loading greater than 0.30 . It also complied with the criterion of item-factor discriminant validity, in which the item loads with a factor loading greater than 0.30 only on the factor where it belongs. Finally, we also complied with the principle that the final solution must be higher than $40 \%$ of the total variance explained and that there must be a match between the theoretical structure and the factor structure found.

In the study of reliability, the homogeneity and internal consistency of the items for the total scale and its dimensions were analysed. Cronbach's alpha internal consistency coefficient and the corrected item-total correlation coefficient were calculated. Finally, summary statistics, descriptive statistics and inferential results of differences for the means related to training in palliative care and gender were calculated, with the latter complying with the criterion of discriminant validity.

All ethical and legal requirements to conduct research were met, namely the request for authorisation from the Board of Directors of the Hospital, which was accepted, and the informed consent by the study participants.

Data were analysed using IBM SPSS Statistics, version 22.

\section{Results}

The translated version of the Coping with Death Scale, entitled Escala de Coping com a Morte - ECM, was applied to the sample under study and its reliability and validity were analysed.

The sample was composed of 107 nurses who worked in the hospitalisation services of an oncologic hospital. Most of them were women (76.6\%). Their mean age was 38.43 years $(S D=8.45$ ), ranging from 27 to 62 years. Most of them had a Bachelor's Degree (57\%) and only 2.8\% had a Bacharelato (3-year degree). The remaining had post-graduate education. In this sample, $42.1 \%$ held the category of nurse, $50.5 \%$ were graduated nurses, and $7.5 \%$ were head or specialist nurses. The years of service varied from four to 43 , with a mean of 15.47 years $(S D=8.04)$.

All nurses provided post-mortem care but only 43.9\% cared for agonic cancer patients. In the sample, $53.3 \%$ had never had training in palliative care and $46.7 \%$ had already received training in this area.

The analysis of the internal consistency of the total scale of coping with death (30 items) showed a $\alpha=$ 0.85 , but the corrected item-total correlations of four items - 1 (Thinking about death is a waste of time), 4 (I am aware of the full array of services from funeral homes), 13 (My attitude about living has recently changed) and 24 (I may say the wrong thing when I am with someone mourning), showed scores below 0.20 and/or were negative, having been deleted. In particular, items 13 and 24 showed negative correlations, even after inversion suggested by the author, in addition to having very low corrected itemtotal correlations $(<0.10)$. Items 1 and 4 had been controversial regarding their content, thus confirming the interest of having them deleted. The 26 final items showed a Cronbach's alpha of 0.89 , which corresponds to a very reliable instrument (Table 1). 
Table 1

Statistics regarding homogeneity and internal consistency of the items of the ECM*

\begin{tabular}{|c|c|c|c|c|}
\hline Item & $\begin{array}{c}\text { Scale mean if item } \\
\text { deleted }\end{array}$ & $\begin{array}{c}\text { Scale variance if item } \\
\text { deleted }\end{array}$ & $\begin{array}{c}\text { Corrected item-total cor- } \\
\text { relation }\end{array}$ & $\begin{array}{l}\alpha \text { if item } \\
\text { deleted }\end{array}$ \\
\hline 02 & 116.91 & 376.73 & 0.54 & 0.89 \\
\hline 03 & 117.40 & 383.30 & 0.44 & 0.89 \\
\hline 05 & 117.25 & 386.62 & 0.28 & 0.90 \\
\hline 06 & 115.99 & 393.75 & 0.31 & 0.89 \\
\hline 07 & 116.93 & 378.31 & 0.36 & 0.89 \\
\hline 08 & 117.80 & 370.82 & 0.55 & 0.89 \\
\hline 09 & 117.93 & 370.12 & 0.57 & 0.89 \\
\hline 10 & 116.08 & 390.89 & 0.33 & 0.89 \\
\hline 11 & 117.15 & 375.69 & 0.43 & 0.89 \\
\hline 12 & 117.13 & 372.13 & 0.56 & 0.89 \\
\hline 14 & 116.08 & 377.55 & 0.60 & 0.89 \\
\hline 15 & 115.96 & 377.04 & 0.62 & 0.89 \\
\hline 16 & 114.67 & 400.41 & 0.29 & 0.89 \\
\hline 17 & 114.90 & 387.19 & 0.52 & 0.89 \\
\hline 18 & 116.14 & 375.58 & 0.53 & 0.89 \\
\hline 19 & 115.77 & 390.46 & 0.34 & 0.89 \\
\hline 20 & 116.78 & 377.63 & 0.53 & 0.89 \\
\hline 21 & 117.36 & 370.23 & 0.57 & 0.89 \\
\hline 22 & 115.69 & 384.06 & 0.54 & 0.89 \\
\hline 23 & 117.47 & 382.12 & 0.39 & 0.89 \\
\hline 25 & 115.93 & 384.87 & 0.41 & 0.89 \\
\hline 26 & 116.01 & 382.33 & 0.55 & 0.89 \\
\hline 27 & 116.04 & 376.17 & 0.59 & 0.89 \\
\hline 28 & 116.27 & 384.92 & 0.57 & 0.89 \\
\hline 29 & 115.70 & 387.95 & 0.46 & 0.89 \\
\hline 30 & 115.31 & 386.31 & 0.51 & 0.89 \\
\hline \multicolumn{5}{|c|}{ Cronbach's alpha (26 items) $=0.893$} \\
\hline
\end{tabular}

*Items 1, 4, 13 and 24 were deleted due to low corrected item-total correlation.

The analysis of construct validity through the principal components analysis was performed with the 26 items, followed by orthogonal varimax rotation, with Kaiser normalisation and Bartlett's test of sphericity. In relation to the decision on the number of factors to retain in the analysis, an exploratory analysis was first performed. This analysis showed some problems related to the number of factors and items, such as their dispersion, the low percentage of variance explained and the low factor loadings. Thus, we used the suggestion of the author as criterion and not so much the scree plot test that, despite this, was useful for illustrating that two factors stand out unambiguously (Figure 1). 


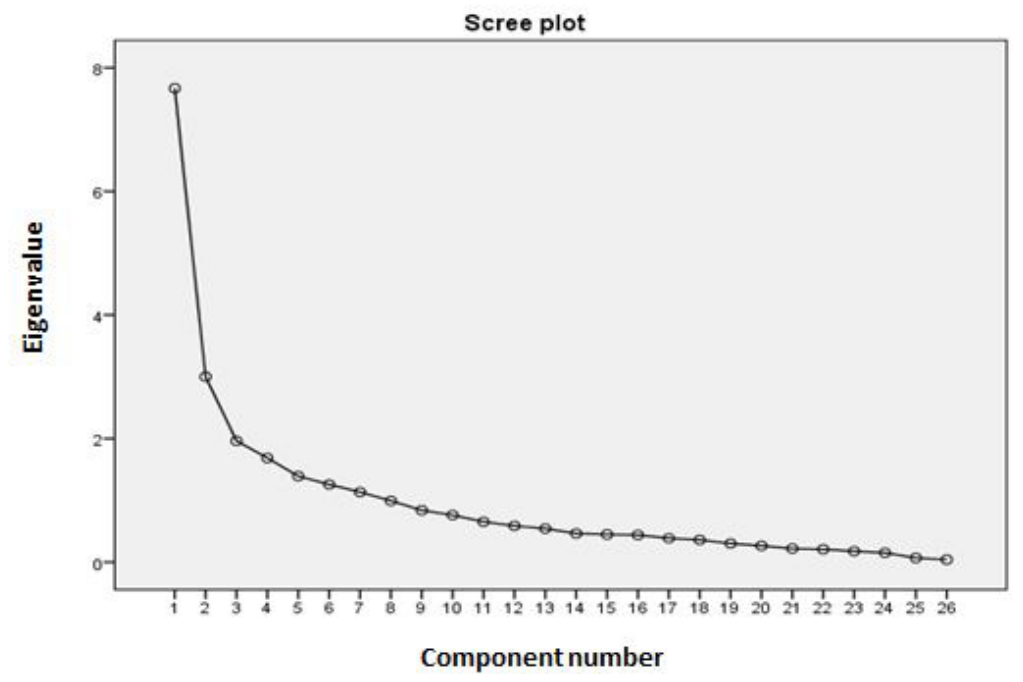

Figure 1. Scree plot.

The two-factor solution proposed was sustained (Table 2 ), and the items were found to be grouped in an identical way as in the original study: 12 items for factor coping with the death of others $(\alpha=0.85)$ and 14 items for factor coping with one's own death $(\alpha=0.86)$.

The KMO measure was 0.81 , which confirms sample adequacy. The Bartlett's test of sphericity was significant $(=1592.10 ; \mathrm{gl}=325 ; \mathrm{p}<0.001)$. The eigenvalues were: $1=7.67 ; 2=3.00$.

The total variance explained was $41.03 \%$ (20.90\% for the first factor and $20.13 \%$ for the second factor), indicating that the factor reduction is adequate to explain that percentage of variance.

Table 2

Item loading and communalities in both factors of the ECM

\begin{tabular}{|c|c|c|c|}
\hline Item & Factor 1* & Factor $2 * *$ & Communalities \\
\hline 2- I have a good perspective on death and dying & & 0.76 & 0.58 \\
\hline 3- Death is an area that can be dealt with safely & & 0.44 & 0.27 \\
\hline 5- I am aware of the variety of options for disposing of bodies & & 0.32 & 0.11 \\
\hline 7- Knowing that I will surely die does not in any way affect the conduct of my life & & 0.58 & 0.34 \\
\hline 8- I feel prepared to face my death & & 0.85 & 0.73 \\
\hline 9- I feel prepared to face my dying process & & 0.83 & 0.69 \\
\hline 10- I understand my death-related fears & & 0.31 & 0.13 \\
\hline 11- I am familiar with prearrangement of funerals & & 0.43 & 0.22 \\
\hline 12- Lately I find it OK to think about death & & 0.65 & 0.46 \\
\hline 14- I can express my fears about dying & & 0.51 & 0.47 \\
\hline 15- I can put words to my gut-level feelings about death and dying & & 0.57 & 0.50 \\
\hline 18- I can talk about my death with family and friends & & 0.50 & 0.38 \\
\hline 20- I will be able to cope with future losses & & 0.54 & 0.35 \\
\hline 21- I feel able to handle the death of others close to me & & 0.58 & 0.42 \\
\hline 6- I am aware of the full array of emotions which characterize human grief & 0.33 & & 0.13 \\
\hline 16- I am making the best of my present life & 0.48 & & 0.24 \\
\hline 17- The quality of my life matters more than the length of it & 0.52 & & 0.38 \\
\hline 19- I know who to contact when death occurs & 0.35 & & 0.16 \\
\hline 22- I know how to listen to others, including the terminally ill & 0.76 & & 0.59 \\
\hline 23- I know how to speak to children about death & 0.42 & & 0.22 \\
\hline 25- I am able to spend time with the dying if I need to & 0.71 & & 0.51 \\
\hline
\end{tabular}


26- I can help someone with their thoughts and feelings about death and dying

27- I would be able to talk to a friend or family member about their death

28- I can lessen the anxiety of those around me when the topic is death and

30- I can tell someone, before I or they die, how much I love them

Cronbach's alpha

$\%$ explained variance

0.59

0.40

$\%$ cumulative explained variance

$0.85 \quad 0.86$

* Coping with the death of others

** Coping with one's own death

Items 6 and 18 loaded on a different factor from the original version, which was accepted given their contents and the factor loadings presented. The factor loadings were all high, greater than 0.30 .

The internal consistency analysed using Cronbach's alpha coefficient of the items in each factor was high. As can be observed in Table 3 , a $\alpha=0.852$ was found for the first factor and a $\alpha=0.858$ was found for the second factor. The corrected item-total correlation was greater than 0.30 in all cases.

Table 3

Internal consistency of both factors of the ECM

\begin{tabular}{|c|c|c|c|c|c|}
\hline $\begin{array}{c}\text { Factor } 1 \\
\text { (Items) }\end{array}$ & $\begin{array}{c}\text { Corrected item-total } \\
\text { correlation }\end{array}$ & $\begin{array}{c}\alpha \text { if item } \\
\text { deleted }\end{array}$ & $\begin{array}{c}\text { Factor } 2 \\
\text { (Items) }\end{array}$ & $\begin{array}{c}\text { Corrected item-total } \\
\text { correlation }\end{array}$ & $\begin{array}{c}\alpha \text { if item } \\
\text { deleted }\end{array}$ \\
\hline 6 &, 308 & 0,855 & 2 & 650 & 0,841 \\
\hline 16 &, 377 & 0,849 & 3 &, 422 & 0,853 \\
\hline 17 & ,483 & 0,843 & 5 & ,302 & 0,862 \\
\hline 19 &, 329 & 0,855 & 7 &, 425 & 0,856 \\
\hline 22 &, 725 & 0,827 & 8 & 686 & 0,838 \\
\hline 23 &, 398 & 0,855 & 9 & 688 & 0,838 \\
\hline 25 & .555 & 0,838 & 10 &, 317 & 0,858 \\
\hline 26 &, 741 & 0,825 & 11 &, 406 & 0,856 \\
\hline 27 &, 575 & 0,837 & 12 & ,614 & 0,843 \\
\hline 28 & 689 & 0,830 & 14 &, 533 & 0,848 \\
\hline 29 & ,680 & 0,830 & 15 &, 591 & 0,846 \\
\hline \multirow[t]{4}{*}{30} &, 565 & 0,838 & 18 &, 474 & 0,851 \\
\hline & & & 20 &, 530 & 0,848 \\
\hline & & & 21 &, 570 & 0,845 \\
\hline & \multicolumn{2}{|c|}{$\alpha=0,852 ; \mathrm{N}^{\mathrm{O}}$ of itens $=12$} & \multicolumn{2}{|c|}{$\alpha=0,858 ; \mathrm{N}^{0}$ of itens $=14$} & \\
\hline
\end{tabular}

As regards the Portuguese version, Escala de Coping com a Morte (ECM), the descriptive statistics showed, in the total score of the scale, the median score of 121.07. It should be noted that this version is composed of 26 items $(\min .=26 ; \max =182)$. The score of coping with death is well above the mean in this sample, but far from the maximum value (Table 4). The score of coping with the death of others shows more favourable mean scores than the coping with one's own death, despite the presence of more items in the first factor.

Table 4

Summary descriptive statistics of the ECM and respective dimensions $(N=107)$

\begin{tabular}{|c|c|c|c|c|c|}
\hline Scale ECM & & Min. & $\operatorname{Max}$. & $M$ & $S D$ \\
\hline Total (26 items) & & 40.00 & 162.00 & 121.07 & 20.27 \\
\hline & Coping with the death of others (12 items) & 17.00 & 79.00 & 63.08 & 9.48 \\
\hline Dimensions & Coping with one's own death (14 items) & 23.00 & 91.00 & 57.99 & 13.76 \\
\hline
\end{tabular}


The differentiation of the scores obtained in the scale according to gender diferences were not statistically significant in terms of coping with death and its dimensions in the sample subjects (Table 5).

Table 5

Student's t-test for independent samples according to gender

\begin{tabular}{lcccccc}
\hline Scale ECM & Gender & $N$ & $M$ & $S D$ & $t$ & $p$ \\
\hline Total (26 items) & $\mathrm{F}$ & 82 & 120.55 & 21.52 & -.476 & .635 \\
& $\mathrm{M}$ & 25 & 122.76 & 15.76 & & \\
Coping with the death of others (12 items) & $\mathrm{F}$ & 82 & 62.90 & 10.06 & -.339 & .735 \\
& $\mathrm{M}$ & 25 & 63.64 & 7.46 & & \\
Coping with one's own death (14 items) & $\mathrm{F}$ & 82 & 57.65 & 14.07 & -.489 & .641 \\
\hline
\end{tabular}

With regard to professional training in palliative care, significant differences were found in terms of coping with death according to whether the nurses had or had not attended these sessions. A higher

Table 6 mean was obtained in those nurses who had received training in this area. However, the differences are not significant in the dimension coping with one's own death (Table 6).

Student's t-test between the ECM and training in PC

\begin{tabular}{lcccccc}
\hline Scale ECM & Training PC & $N$ & $M$ & $S D$ & $t$ & $p$ \\
\hline Total & No & 57 & 117.46 & 18.42 & \multirow{2}{*}{-1.99} & .049 \\
(26 items) & Yes & 50 & 125.18 & 21.66 & & \\
Coping with the death of others (12 & No & 57 & 61.05 & 8.74 & -2.41 & .018 \\
items) & Yes & 50 & 65.38 & 9.85 & & \\
Coping with one's own death (14 & No & 57 & 56.40 & 12.98 & \multirow{2}{*}{-1.28} & .204 \\
items) & Yes & 50 & 59.80 & 14.51 & & \\
\hline
\end{tabular}

\section{Discussion}

The Portuguese version of the scale revealed many similarities with the original scale. The translation and adaptation revealed no difficulties and its internal consistency is very good. However, since four items showed a low corrected item-total correlation or negative correlation, even after items 13 and 24 were inverted, we found it appropriate to remove them. Indeed, its construct validity seemed to be compromised and, by re-examining the content of the items, we found it appropriate not to keep them. The internal consistency of the 26-item scale improved and Cronbach's alpha increased from 0.85 to 0.89 , which is a value similar to that of the original scale. The forced two-factor solution, as in the original proposal, has many similarities with the original version as regards item distribution, with the exception of items 6 and 18. The factor loading of item 18 is higher in the second factor, coping with one's own death, and the factor loading of item 6 is higher in the first factor, coping with the death of others. These differences may be due to the sampling or cultural contexts in which the scale was studied and so they were accepted. This option is due to the fact that item 18 points to the communication with others about death, which fits into the second factor, and item 6 points to the personal knowledge about the emotions, which fits the first factor. The internal consistency of each factor is high. These values were not presented by Bugen (1980-81), in his original version, or by Robbins (1990-91), in the adaptation of the original version.

The nurses scored high levels of coping (above average), revealing the numerous mechanisms of resilience that they mobilise to control their emotions and anxiety (Popim \& Boemer, 2005). These characteristics translate into a professional advantage given the type of service where they work. Gender had no influence in coping. 
Regarding training in palliative care, nurses who had received training in this area had higher levels of coping than those who had not received, but only in total coping and in the dimension coping with the death of others. The dimension coping with one's own death did not change with training. This result is very interesting and refers to the importance of conducting studies with other psychological variables on their relationship with the representation of death, particularly attitudes and anxiety.

\section{Conclusion}

The scale showed good psychometric properties and therefore proved useful to be applied in further studies. According to the author of the scale, coping with death is an ability that represents a key dimension in the assessment of the effects of death education. The lack of evidence of validation on the positive benefits of death education may be partly a result of an excessive focus on attitudes, on bioethical issues and on the trait measures of concern with death. These issues may not be as sensitive to change as coping.

To sum up, we believe that, given the fact that sample size as a limitation, the validation study of the scale must continue, both with a larger sample of nurses and with the general population.

\section{References}

Beckstrand, R. (2009). Oncology nurses ' perceptions of obstacles and supportive behaviors at the end of life. Oncology Nursing Forum, 36(4), 446-453.

Braun, M., Gordon, D., \& Uziely, B. (2010). Associations between oncology nurses' attitudes toward death and caring for dying patients. Oncology Nursing Forum, 37(1), 43-49.

Bugen, L. (1980-81). Coping: Effects of death education. Omega Journal of Death and Dying, 11(2), 175-183.

Dunn, K., Otten, C., \& Stephens, E. (2005). Nursing experience and the care of dying patients. Oncology Nursing Forum, 32(1), 97-104.

Ferreira, P. L., \& Rosete, M. L. (1996). Metodologia para avaliação cultural de instrumentos de medição do estado de saúde. In A. M. Vaz, C. G. Pinto, F. Ramos, \& J. A. Pereira (Eds.), As reformas dos sistemas de saúde (pp. 255-265). Lisboa, Portugal: APES. -
Fessick, S. (2007). The use of a staff retreat with a grief counsellor for inpatient medical oncology nurses to assist with bereavement and coping. Oncology Nursing Forum, 34(2), 529.

Hunt, S. M. (1993). Cross-cultural comparability of measures and other issues related to multicountry studies. British Journal of Medical Economics, 6, 27-34.

Lazarus, R. (1993). Coping with the stress of ilness. In A. Kaplun (Ed.), Health promotion and chronic illness: Discovering a new quality of health (11-29). Copenhagen: WHO, Regional Office for Europe.

Lobb, E., Oldham, L., Vojkovic, S., Kristjanson, L. J., Smith, J., Brown, J. M., ... Dwyer, J. M. (2010). Frontline grief: The workplace support needs of community palliative care nurses after the death of a patient. Journal of Hospice and Palliative Nursing, 12(4), 225-233.

Loureiro, L. M. (2010). Tradução e adaptação da versão revista da Escala de Avaliação do Perfil de Atitudes Acerca da Morte (EAPAM). Revista Referência, 3(1), 101-108. doi: 10.12707/RII1012

Lynn, M. R. (1986). Determination and quantification of content validity. Nursing Research, 35(6), 382-385.

Mishel, M. H. (1998). Methodological Studies: Instrument Development. In P. J. Brink \& M. J. Wood. Advanced Design in Nursing Research (2 ${ }^{\text {nd }}$ ed. pp. 235-282).Thousand Oaks, CA: Sage Publications.

Pais-Ribeiro, J. L. (2007). Investigação e avaliação em psicologia da saúde. Lisboa, Portugal: Climepsi.

Pocinho, M. \& Capelo, M. (2009). Vulnerabilidade ao stress, estratégias de coping e autoeficácia em professores portugueses. Educação e Pesquisa, 35(2), 351-367.

Popim, R. \& Boemer, M. (2005). Cuidar em oncologia na perspetiva de Alfred Schutz. Revista Latina Americana de Enfermagem, 13(5), 677-685.

Rickerson, E. M., Somers, C., Allen, C. M., Lewis, B., Strumpf, N., \& Casarett, D. J. (2005). How well are we caring for caregivers? Prevalence of grief-related symptoms and need for bereavement support among long-term care staff. Journal of Pain and Symptom Management, 30(3), 227-233.

Robbins, R. (1990-91). Bugen's coping with death scale: Reliability and further validation. Omega - Journal of Death and Dying, 22(4), 287-299.

Santos, J., \& Bueno, S. (2011). Educação para a morte a docentes e discentes de enfermagem: Revisão documental da literatura científica. Revista da Escola de Enfermagem da USP, 45(1), 272-276.

Stumm, E., Leite, M. T., \& Maschio, G. (2008). Vivências de uma equipe de enfermagem no cuidado a pacientes com câncer. Cogitar em enfermagem, 13(1), 75-82,

Vaz-Serra, A. (2000). A vulnerabilidade ao stress. Psiquiatria Clinica, 21(4). 
